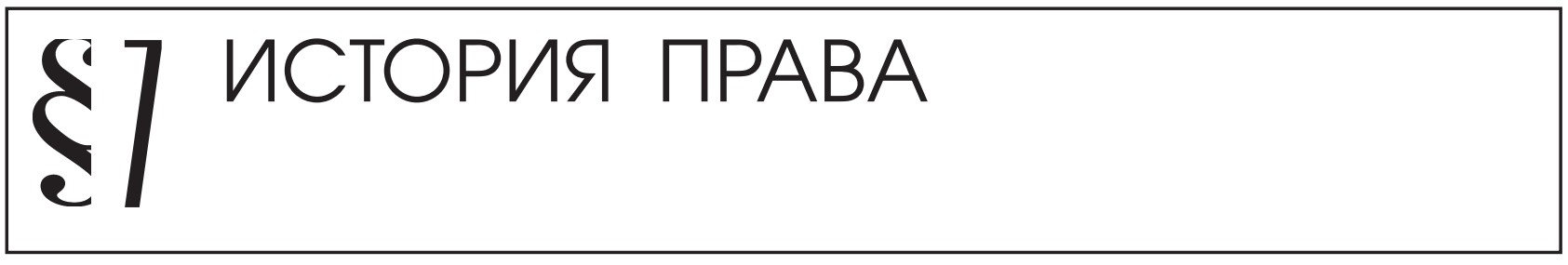

Кодан С.В.

\title{
ИСТОЧНИКИ ЛИЧНОГО ПРОИСХОЖДЕНИЯ КАК НОСИТЕЛИ ИСТОРИКО-ЮРИДИЧЕСКОЙ ИНФОРМАЦИИ
}

Аннотация: B статье представлены положения, связанные с использованием источников личного происхождения в изучении истории государственно-правового развития России. Если данный вид письменных носителей информации прочно укоренился в исторических и литературоведческих исследованиях, то в юридических науках его возможности используются весьма незначительно. Историками ХVIII - начала ХХІ столетий наработан обширный источниковедческий материал, связанный с понятием источников личного происхождения. Со второй половины ХІХ в. и историки права активно обращуались к пониманию значения данного вида носителей исторической информации в исследованиях историко-юридического плана, достаточно широко использовали данный вид информации при явлений юридического характера. Вместе с тем в современных работах историков права и юристов-отраслевиков источники личного происхождения используются незначительно и чаще всего, выполняют функиию иллюстрации представленного исследовательского материала. Методология данной статьи опираются на уже сложившиеся подходы к изучению источников личного происхождения в ичелях их адаптаџии для юридического исследования. Научная новизна работь состоит в обобщении уже сложившихся в различных гуманитарных науках (истории, литературоведении и др.) различных методологических и методических подходов к изучению и использованию носителей информации личностного характера с учетом возможностей их применения в исторических и отраслевых правовых исследованиях. Review: The article contains provisions that are related to using personal sources in studying the history of state legal development of Russia. While the written sources are widely used in historical and literary researches, legal sciences use them quite rarely. Historians of the XVIIIth - early XXIth centuries developed rich historiographic data based on personal sources. Starting from the second half of the XIXth century, historians of law actively used personal sources in their researches of legal phenomena. At the same time, in recent researches on history of law and branches of law personal sources are used quite rarely and often as an illustration. Methodology of the present research article is based on established approaches to studying personal sources for the purpose of their adaptation to legal researches. The scientific importance and novelty of the article is that the author of the article summarizes different methodological and technical approaches to studying personal sources of information that are usually used in the humanities (history, literary studies and etc.) and analyzes their capacities for carrying out historical and regional law researches.

Ключевые слова: Юриспруденция, история права, источники изучения права, письменные историко-юридические, классификация историко-юридических источников, источники личного происхождения, дневники, переписка, мемуары, сказания иностранцев.

Keywords: law studies, history of law, sources of law studies, written sources, personal sources, historical law sources, diaries, correspondence, memoirs, stories told by foreigners.

И сточники личного происхождения в исторических исследованиях прочно укоренились качестве носителей информации, дополняющих и иллюстрирующих полученные из других источников сведения. Историками XVIII - начала XXI столетий наработан обширный источниковедческий материал, связанный с понятием источников личного происхождения. Со второй 
половины XIX в. и историки права активно обращались к пониманию значения данного вида носителей исторической информации в исследованиях историко-юридического плана, достаточно широко использовали данный вид информации при изучении явлений юридического характера. Вместе с тем в современных работах историков права источники личного происхождения используются незначительно и чаще всего, выполняют функцию иллюстрации представленного исследовательского материала. В рамках данной статьи представим ряд положений, связанных с использованием указанного вида носителей информации в изучении истории государственно-правового развития России.

1. Источники личного происхождения как носитель информации о прошлом. Источники личного происхождения представляют особую группу носителей сведений о прошлом. Как письменные источники они выделены по признаку их происхождения - от конкретного человека. Их источниковедческий анализ и значение получили детальное рассмотрение в исторической науке, а активное использование в качестве источников присутствует в различных сферах получения гуманитарного знания. Исторические, культурологические, литературоведческие, лингвистические и др. исследования активно опираются на источники личного происхождения, которые дают возможность более глубоко понять происходящее в контексте личности и эпохи.

Понятие источников личного происхождения имеет принципиальное значение для определения их места в системе носителей исторической информации. Общее определение понятия данного вида источников прошло длительный процесс и в теоретическом плане и все еще находится в стадии осмысления. Тем не менее, основные методологические подходы в теории источниковедения сложились и определены основные направления изучения источников личного происхождения.

2. Методологические подходы к пониманию источников личного происхождения в современном историческом источниковедении получили разработку в двух взаимосвязанных между собой направлениях - информационном, коммуникативном и биографическим. Они содержат исходные положения, связанные с пониманием данного вида источников.

Информационный подход позволяет рассматривать источники личного происхождения как носите- ли исторической информации о прошлом, которые в письменной форме отражают реальную действительность прошедшего времени. В рамках данного подхода значение имеет характеристика информационного процесса и способ кодирования информации. Он базируется на том, что «возникновение большинства исторических источников представляет собой информационный процесс, в котором фигурируют объект - отражаемая реальность, субъект - творец источника, и информация - результат отражения объекта субъектом. Этот процесс, как и всякий информационный, всегда имеет прагматический аспект, т.е. творец источника всегда преследует определенную цель, выявляя сведения об объективной действительности. Эти сведения требуются для решения тех или иных общественных или личных задач. То, что потом стало исторической информацией, зафиксированной в исторических источниках, первоначально являлось информацией, необходимой для удовлетворения практических нужд. Это в одинаковой мере относится и к законодательству, и к правовым актам, фиксировавшим и регулировавшим те или иные отношения, и к личной переписке, и к мемуарам, которые преследовали цель самовыражения, самоосознания и самоутверждения личности» - отмечает И.Д. Ковальченко ${ }^{1}$. При этом необходимо учитывать и способ кодирования информацчии - с той точки зрения источники личного происхождения включаются в число письменных исторических источников, поскольку они содержат, как указывает Л.Н. Пушкарев, «информацию, которую выработал человек, отображающий реальную действительность, и закодировал ее в тех или иных знаках, словах, сигналах и т.п.»².

В рамках информационного подхода можно говорить и рассмотрении историками права источников личного происхождения как носителей сведений о прошлом государственно-правового развития России. Так, например, Н.П. Загоскин, предлагая классификацию источников «истории права», выделял данный вид указанных источников: «1) памятники вещественные, 2) летописи и хронографы, 3) памятники государственного и юридического быта, 4) памятники устной и письменной словесно-

${ }^{1}$ Ковальченко И.Д. Методы исторического исследования. М., 1987. С. 115.

${ }^{2}$ Пушкарев Л.Н. Классификация русских письменных источников по отечественной истории. М., 1975. С. 95. 


\section{Политика и общество 3 (111) • 2014}

сти, 5) записки (мемуары) и письма современников и 6) сказания иностранцев» и описывает их ${ }^{3}$.

Коммуникативный подход связан с изучением источников личного происхождения в контексте «концепции индивидуализации человека». Ее суть состоит в том, что посредством установления «вторичных связей» между человеком и обществом происходит осознание им своего места в двух пространствах коэкзистенциальном (осознание связи со своей социально-культурной средой - эпохой, современниками, с конкретной социальной группой и т.п.) и эволюционном (осознание связи с предыдущими и последующими поколениями, хода исторического времени). М.Ф. Румянцева, исходя из данного подхода, указывает, что «источники личного происхождения ... наиболее последовательно воплощают процесс самосознания личности и становление межличностных отношений ${ }^{4}$. Данный подход позволяет взглянуть на источники личного происхождения в контексте личностного восприятия и преломления исторической информации, проанализировать включенность автора в события и эпоху.

Биографический подход непосредственно связан с источниками личного происхождения и предполагает изучение особенности жизненного пути и продуктов творчества отдельной личности, что особенно важно при анализе и раскрытии их информационного потенциала в историческом исследовании. Появление и развитие научного направления в истории и науковедении, получившее название «биографика», позиционируется в качестве «синтетической» науки о человеке и ставит ряд проблем, связанных и источниками создания биографий, среди которых источники личного происхождения играют решающую роль. При этом и сама биография автора источника, воссозданная биографом, имеет информационное значение в изучении и критике самого носителя исторической информации личного характера. На этом пересечении источниковедения и биографики исследователь получает возможности изучения самого автора источника личного происхождения в целях реализации конкретного исследовательского проекта 5 .

3 Загоскин Н.П. Курс истории русского права. Казань, 1906. T. 1. C. 64-87.

${ }^{4}$ Румянцева М.Ф. Исторические источники XVIII - начала XX века // Данилевский И.Н., Кабанов В.В., Медушевская О.М., Румянцева М.Ф. Источниковедение: Теория. История. Метод. Источники российской истории. М., 1998. С. 466.

${ }^{5}$ Петровская И.Ф. Биографика. Введение в науку и обозре-
Итак, указанные методологические подходы к пониманию источников личного происхождения в современном историческом источниковедении обеспечиваю учет сложной природы данного вида письменных источников познания прошлого. Рассматривая данный вид источников в контексте информационного процесса, в источниковедении особенно подчеркивается и имеет значение отраженная в них не только историческая информация, но и ее личностная индивидуализация событий прошедших преломление через участника или наблюдателя происходящих событий, связанная с его жизненным путем - биографией. Это переопределяет необходимость формирования общего понятия источников личного происхождения и их классификации.

\section{2. Понятие источников личного происхождения.} Определение понятие источников личного происхождения и их классификация имеет решающее значение, поскольку позволяет выделить их в системе исторических источников, а также определить общие характеристики данного вида носителей информации о прошлом. Определения понятия также создает общие ориентиры для исследователя во всей палитре носителей информации о прошлом. Общее понятие источников личного происхождения в историческом источниковедении связано с обозначенными выше методологическими подходами. Исходя из них определение источников личного происхождения сосредоточено вокруг двух понятий - мемуаристика и личностно-коммуникационнье письменные источники.

Мемуаристика как общее понятие источников личного происхождения выделяет их как вид носителей исторической информации охватывает и все разновидности носителей информации личностного характера и условно относит все их разновидности к мемуарам. Оно сформировалось в рамках информационного подхода и отнесения данного вида источников к письменным источникам русской истории.

«Мемуаристика» как обозначение источников личного происхождения происходит от термина «мемуары» (франц. mémoires, лат. memoria - память). Под мемуарами в различное время понимались: в конце XIX в. - «записки современников - повество-

ние источников биографических сведений о деятелях России 1801-1917 годов. СПб., 2003. См. также: Баженова Т.М., Кодан С.В. Личность, творчество и практическая деятельность юристов как отражение развития российской юриспруденции XI - начала XX вв. // Российское правосудие. 2010. № 9. 
вания о событиях, в которых автор мемуаров принимал участие или которые известны ему от очевидцев» (Энциклопедический словарь, Ф.А. Брокгауз и И.А. Эфрон $)^{6}$. Российские историки и историки права рассматривали данный вид исторических источников именно в данном ключе. Так, Н.П. Загоскин указывал - «Под записками (мемуарами) современников разумеются повествования об известных событиях лиц, или бывших очевидцами данных событий, или же слышавших о них от других лиц, а равно почерпнувших сведения из каких либо других источников» ${ }^{7}$.

В XX в. мемуары определялись как «воспоминания автора об исторических событиях, участником или очевидцем которых он был, один из видов источников исторических» (Советская историческая энциклопедия $)^{8}$. В литературоведении мемуары рассматриваются как «разновидность документальной литературы и в то же время один из видов так называемой исповедальной прозы. Представляет собой повествование участника или свидетеля общественно-политической, социальной, литературно-художественной жизни о событиях, свидетелем или действующим лицом которых он был, а также о людях, с которыми он общался» (Литературная энциклопедия терминов и понятий $)^{9}$. Достаточно четкое, емкое и лаконичное определение мемуаров дает А.Г. Таратаковский, и пишет о них «как повествованиях о прошлом, основанных на личном опыте и собственной памяти автора» ${ }^{10}$.

В современном источниковедении в рамках данного направления источники личного происхождения называются «мемуаристика». А.Г. Тартаковский обозначает ее следующим образом - «Мемуаристика (в широком смысле слова) суть овеществленная историческая память, одно из средств духовной преемственности поколений и один из показателей уровня цивилизованности общества, его сознательного отношения к своему прошлому, а следовательно, к своему бы-

\footnotetext{
${ }^{6}$ Мемуары // Энциклопедический словарь. Т. 19. СПб, 1896.

7 Загоскин Н.П. История права русского народа. Казань, 1899. T. 1. C. 221.

${ }^{8}$ Биск И.Я. Мемуары // Советская историческая энциклопедия. М., 1966. Т. 9. С. 343.

${ }_{9}^{9}$ Якушева Г.В. Мемуары // Литературная энциклопедия терминов и понятий. М., 2001. С. 524

${ }^{10}$ Тартаковский А.Г. 1812 год и русская мемуаристика. М.,
} 1980. C. 22-23. тию вообще» ${ }^{11}$. Более четкое определение предложено И.Л. Сиротиной - «Мемуаристика - это повествование или размышление о действительно бывшем, основанное на личном опыте и собственной памяти автора». Данным автором предлагается классификация мемуаров и выделяются «1. Мемуары-летописи (созданные непосредственно вслед за событиями, по горячим впечатлениям): дневники, письма, записки, путевые заметки и др. 2. Мемуары-воспоминания (созданные по прошествии некоторого времени, по памяти): автобиографии, воспоминания, литературные портреты, исповеди и др. 3. Художественные мемуары (созданные отчасти по памяти, отчасти с использованием записей, публикаций разных лет, собственных прежних воспоминаний, мемуаров других авторов, писем своих и чужих и т.п.): как правило, литературно подготовленные, отредактированные, художественно оформленные произведения» ${ }^{12}$.

При этом заметим, что обозначение источников личного происхождения как «мемуаристика» не дает возможность отграничить мемуары от других разновидностей данного вида источников, поскольку к мемуарам нередко относят дневники, автобиографии, письма и т.п. В рамках данного определения не происходит учета специфики отдельных разновидностей источников личного происхождения, что принципиально разно для раскрытия их характеристик и учета их особенностей в исследовательской деятельности.

Личностно-коммуникационные письменные источники рассматриваются как отражение в источниках личного происхождения восприятия, передачи и интерпретации происходивших событий с учетом направленности коммуникативных связей лица и окружающего его социального пространства. Общее понятие источников личного происхождения менее четко определено, но детализируется и раскрывается через их функции. М.Ф. Румянцева указывает, что «источники личного происхождения - группа видов исторических источников, функцией которых является установление межличностной коммуникации в эволюционном и коэкзистенциальном целом и автокоммуникации» и выделяет их виды - «к источникам личного

\footnotetext{
${ }^{11}$ Тартаковский А. Г. Русская мемуаристика XVIII - первой половины ХІХ вв. М., 1991. С. 3.

12 Сиротина И.Л. Культурологическое источниковедение: проблема мемуаристики // Методология гуманитарного знания в перспективе XXI в. Мат. межд. научн. конф. СПб., 2001. Cep. «Symposium». Вып. № 12. С. 227, 231.
} 


\section{Политика и общество 3 (111) • 2014}

происхождения относятся дневники, частная переписка (эпистолярные источники), мемуары-автобиографии, мемуары - «современные истории», эссеистика, исповеди». При этом при рассмотрении источников личного происхождения внимание исследователя акцентируется на «направленность устанавливаемых ими коммуникационных связей» ${ }^{13}$.

В контексте предложенных методологических подходов понятие источников личного происхождения как носителей исторической информации отражает их место в письменных исторических источниках и особенности содержания. В итоге можно ориентироваться на следующее общее понятие.

Источники личного происхождения - письменные исторические источники, которые отражают личностное восприятие произошедиих событий $и$ фиксируют их на документально-субъективном уровне в различной форме, отражающих прошедшую через память информацию о прошлом с учетом личного опыта и социально-коммуникационных связей автора.

3. Свойства источников личного происхождения отражают их общие характеристики как источников знания о прошлом. Для них характерны три основных свойства - ретроспективность, документальность и субъективность, которые связаны именно с проявлением индивидуального, личного начала в исторических источниках данного вида. Эти свойства позволяет раскрыть их особенности данного вида и учесть специфику использования в историческом исследовании. На сочетание этих сторон данного вида источников обращается особое внимание в историческом источниковедении.

Ретроспективность источников личного происхождения характеризует их отношение к историческим событиям как прошлому и связана с отражением в них прошедших фиксируемых событий в виде определенного вида письменных документов свидетельствах прошлого. При этой «обращенности в прошлое» временные уровни этого отражения могут быть различны - относительно синхронны между автором и фиксируемым событием (дневники, переписка) или имеют между ними временной разрыв - сами по себе при отражении прошлого ретроспек-

${ }_{13}$ Румянцева М.Ф. Исторические источники XVIII - начала XX века // Данилевский И.Н., Кабанов В.В., Медушевская О.М., Румянцева М.Ф. Источниковедение: Теория. История. Метод. Источники российской истории. М., 1998. C. 466-467. тивны, который может быть весьма значительным (мемуары). По их поводу И.Л Сиротина подчеркивает - «Ретроспективность - необходимая и неотъемлемая черта мемуаристики. Это относится практически ко всем источникам личного происхождения, а не только к мемуарам, т.к. «между временем написания мемуарного произведения и воссоздаваемыми событиями всегда лежит временной промежуток. Он может быть как совершенно незначительным (в дневниках, письмах, путевых заметках), так и сколь угодно большим (в автобиографиях, литературных портретах, очерках, воспоминаниях)» ${ }^{14}$.

Ретроспективный характер источников личного происхождения сказывается как на характере представляемой в них информации, так и их значении как на уникальном историческом источнике, фиксирующем сведения, которые не присутствуют в других письменный исторических источниках и даже не могли быть воспроизведены в иных других носителях данных о прошлом. При этом именно данный вид источников создает для современного исследователя новые возможности получения и интерпретации исторической информации. В этом отношении необходимо учитывать, что ретроспективность находит отражение в степени документальности источников личного происхождения.

Документальность источников личного происхождения характеризует их точки зрения отражения фактических событий прошлого, свидетельств о нем. Источники личного происхождения - это документы, которые сообщают об исторических событиях. Документальность данного вида источников неразрывно связана с уровнем включенности автора в описываемые события и, соответственно, информационная ценность отдельного источника личного происхождения определяется непосредственным участием в событиях или описанием их со слов других. Но при этом необходимо учитывать главную особенность источников личного происхождения - «субъективность документальности», поскольку историческая информация прошла через сознание и восприятие современника исторических событий, связана с его памятью и личной биографией, отражает при передаче информации личные взгляды и позиции автора.

В зависимости от разновидности источника личного происхождения документирование событий может

${ }^{14}$ Сиротина И.Л. Культурологическое источниковедение: проблема мемуаристики... С. 228 
происходить в различных формах - мемуарах, дневниках, личной переписке, имеющих свои особенности передачи информации о прошлом. При этом документальность неразрывно связана с временным фактором - отдаленностью времени написания источника от времени самого события, что во многом определяет документальность последнего. В связи с этим важно учитывать замечании П.А. Зайончковского о том, что «каждый из этих типов источников имеет свои положительные и отрицательные стороны. Так, дневники по своей природе более достоверны, нежели воспоминания. Им присуща свежесть восприятия, а следовательно, и более достоверное описание того или иного события. Воспоминания обычно пишутся спустя известное время после происходящих событий, когда кое-какие детали могут быть забыты. Но при этом события в них освещаются более систематично» ${ }^{15}$.

Документальность источников личного происхождения может вступать в определенное противоречие с фактической точностью передаваемой информации, которая может требовать уточнения по другим источникам. Так, например, мемуары выступают как документально-литературные произведения и отражают «особое качество документальной литературы, - отмечает Л. Гинзбург, - в той установке на подлинность, ощущение которой не покидает читателя, но которая далеко не всегда равна фактической точности» ${ }^{16}$. Поэтому документальность этого вида источников неразрывно связана с его субъективностью.

Субъективность источников личного происхождения как их свойство характеризует их зависимость от его взглядов, суждений, мнений, представлений и т.п. автора источника. Авторская субъективность в той или иной степени является неотъемлемым свойством всех источников данного вида. Отмечая это свойство источников личного происхождения (относительно мемуаров), В.В. Кабанов подчеркивает, что они «как никакой другой документ, субъективны. Это не недостаток, а свойство мемуаров, ибо они несут на себе отпечаток личности автора. Все достоинства и недостатки мемуариста невольно переходят и на воспоминания. В противном случае мемуары безлики» ${ }^{17}$. Следует учитывать, что ввтор источника личного происхождения

15 Зайончковский П.А. Введение // История дореволюционной России в дневниках и воспоминаниях. М., 1976. С. 4.

${ }^{16}$ Гинсбург Л.Я. О психологической прозе. М., 1999. С. 7.

${ }^{17}$ Кабанов В.В. Источниковедение истории советского общества. Курс лекций. М., 1997. С. 133. именно через личное отношение (с учетом служебного положения, межличностных связей, взглядов, эмоционального настроя и т.п.) отбирает информацию и фиксирует ее письменно. При этом в этой субъективности источников личного происхождения содержится некое «относительно объективное» содержание, которое позволяет обеспечить соприкосновение исследователя с прошлым, «проникновение» в него, его понимание через личность автора источника и описываемые им события. По этому поводу Л.П. Репина подчеркивает, что «при отсутствии прямого контакта с прошлой реальностью, мы лишены возможности познать какой-то ситуативный опыт прошлого в отдельности, но его можно понять в более широком контексте, в комплексной картине исторического опыта, включающей самые разные его интерпретации. В субъективности мемуаров как источников отражены взгляды и предпочтения, система ценностей людей - авторов этих свидетельств. Соответственно, субъективность, через которую проходит и которой отягощается конкретная информация, отражая представления, в большей или меньшей степени характерные для некой социальной группы или для общества в целом, проявляет культурно-историческую специфику своего времени» ${ }^{18}$.

Субъективность источников личного происхождения непосредственно связана с временным разрывом между описываемым событием и временем написания носителя исторической информации, что может повлиять на определенное искажение отражаемого автором факта. Исходя из этого необходимо учитывать «уровень субъективности» отдельных видов источников личного происхождения. Относительно низкий уровень субъективности характерен для дневниковых записей, (представляют заметки непосредственно или по прошествии короткого времени после события) и писем (чаще всего связаны с происходящими, близкими по времени написания событиями). Самый же высокий уровень субъективности присущ для мемуаров, которые писались, как правило, по прошествии многих лет, могли преследовать сугубо личные цели и даже быть направленными на искажение сведений о происходивших событиях ${ }^{19}$.

\footnotetext{
${ }^{18}$ Репина Л.П. Концепции социальной и культурной памяти в современной историографии. М., 2005. С. 128.

19 Сиротина И.Л. Культурологическое источниковедение: проблема мемуаристики // Методология гуманитарного знания в перспективе XXI в. Мат. межд. научн. конф. СПб., 2001. Cep. «Symposium». Вып. № 12.
} 


\section{Политика и общество 3 (111) • 2014}

Анализируя источники личного происхождения в контексте субъективного восприятия прошлого и предаваемой в них исторической информации, необходимо учитывать, что реальность воспроизводится в письменных источниках. В них на основе памяти происходит реконструкция прошедших на глазах автора событий, а затем в письменном виде излагаются впечатления, размышления и т.п. Особую роль в этих процессах играет память как одна из психических функций и видов умственной деятельности человека, предназначенная сохранять, накапливать и воспроизводить информацию. Но при этом необходимо учитывать и особенности памяти человека, которая подвергает отражаемую информацию определенным изменениям на объективном и социальнопсихологическом уровнях. Объективный характер определенных искажений отражения прошлого в источниках личного происхождения связан с особенностями памяти человека - изменениями в проходящей через нее информации, уровень достоверности которой при этом объективно снижается. В памяти человека (согласно теории перекодирования Дж. Миллера) происходит определенное субъективное искажение данных - происходит их «уравнивание» (многие черты воспринимаемого явления нивелируются и история событий принимает более схематичный, упрощенный вид) «уточнение» (некоторые из оставшихся в памяти деталей, порой второстепенных, приобретают особую значимость, подчеркиваются автором) и «ассимиляция» (событие запоминается и воспроизводится в соответствии с желаниями и приоритетами) $)^{20}$.

В социально-психологическом плане источники личного прохождения отражают прошедшую через память человека информацию, которая трансформировалась не только с учетом объективных особенностей памяти, но и по влиянием социальных факторов.Наэтообращалвниманиепсихологифилософ С.Л. Рубинштейн - «В нашей «исторической» памяти, воспроизводящей наше прошлое, особенно отчетливо выявляется значение для формирования памяти требований, предъявляемых к человеку социальными отношениями, в которые он вступает. Необходимость действовать в дальнейшем в соответствии с характером

${ }^{20}$ Миллер Дж.А. Магическое число семь плюс или минус два. О некоторых пределах нашей способности перерабатывать информацию // Хрестоматия по общей психологии. Психология памяти. М., 1980. обязательств к другим людям влечет за собой необходимость сохранять воспоминания о прошлом. Участие в общественной жизни требует сохранения и уточнения воспоминаний, и оно же дает для этого опорные точки. Мы должны помнить наше прошлое, поскольку оно связано с другими людьми, и именно это участие в коллективной жизни связывает события нашей индивидуальной жизни с событиями коллективного опыта; это дает возможность восстановить первые исходя из вторых. И на памяти человека, следовательно, сказывается то, что он - общественное существо, включенное в общественную жизнь» ${ }^{21}$.

Субъективность отдельных видов источников личного происхождения предопределена и их особенностями как жанра документальной литературы. Необходимо учитывать, что «в мемуарах спорное и недостоверное объясняется не только несовершенной работой памяти или умышленными умолчаниями и искажениями. Некий фермент «недостоверности» заложен в самом существе жанра. Совпасть полностью у разных мемуаристов может только чистая информация (имена, даты и т. п.); за этим пределом начинается уже выбор, оценка, точка зрения. Никакой разговор, если он сразу же не был записан, не может быть через годы воспроизведен в своей словесной конкретности. Никакое событие внешнего мира не может быть известно мемуаристу во всей полноте мыслей, переживаний, побуждений его участников - он может о них только догадываться. Так угол зрения перестраивает материал, а воображение неудержимо стремится восполнить его пробелы - подправить, динамизировать, договорить»- отмечает Л.Я. Гинсбург ${ }^{22}$.

Итак, понятие источников личного происхождения позволяет выделить их на видовом уровне из письменных исторических источников. Оно необходимо для общего понимания содержательного своеобразия данного вида источников изучения прошлого, которое проявляется в разновидностях источников личного происхождения. Свойства источников личного происхождения характеризуют их характерные черты и особенности как вида письменных исторических источников. Соответственно разновидности источников личного происхождения показательны с точки зрения детализации их отдельных характеристик и возможностей использования в исследовании.

\footnotetext{
${ }^{21}$ Рубинштейн С.Л. Память // Хрестоматия по общей психологии. Психология памяти. М., 1979. С. 187.

22 Гинсбург Л.Я. О психологической прозе. М., 1999. С. 7-8.
} 


\section{4. Классификация источников личного про-} исхождения. Вопрос о классификации источников личного происхождения имеет давнюю традицию изучения, особенно значим для определения их разновидностей. Различные подходы к данному вопросу сложились преимущественно в рамках информационного и коммуникативного подходов, рассмотренных выше. С их учетом остановимся на основных разновидностях данного вида исторических источников, к которым относятся дневники, частная переписка, мемуары и «сказания иностранцев».

Дневники как источники личного происхождения представляют собой письменные носители информации - «периодически пополняемый текст, состоящий из фрагментов с указанной датой для каждой записи» ${ }^{23}$. В них автор оперативно (каждодневно или с небольшими временными промежутками) посредством записей фиксируются прошедшие события - дневник «идет вслед за жизнью». Объекты, отражаемые в дневниковых записях, могут относиться к различным сторонам жизнедеятельности общества - государственной, общественной и т.п. Назначение дневников заключается в накоплении информации с возможным ее анализом и использованием в будущем для воспроизведения в памяти прошедшего, анализа прошлого или создания других произведений мемуарного, художественного или др. характера. Они имеют единство формы, определяемое единой структурной единицей, которой выступает повседневная запись информации о самых разнообразных событиях с «временной привязкой» к календарной дате. При этом следует учитывать и их определенную краткость, отрывочность, неполноту в описании событий. Характерная черта дневников их «автокоммуникативный» характер, поскольку они создаются, как правило, не публичного представления - «для себя» или ограниченного круга адресатов, определяемых автором ${ }^{24}$.

Документальность дневников основывается на оперативной фиксации свидетельств очевидцев, их синхронности описываемых событий. Данный вид источников личного происхождения характеризуется более высоким уровнем точности отражения со-

${ }^{23}$ Жожикашвили С.В. Дневник // Литературная энциклопедия терминов и понятий. М., 2001. Стлб. 232.

${ }^{24}$ Румянщева М.Ф. Исторические источники XVIII - начала XX века // Данилевский И.Н., Кабанов В.В., Медушевская О.М., Румянцева М.Ф. Источниковедение: Теория. История. Метод. Источники российской истории. М., 1998. С. 446. бытий на основе указания календарных дат и приведения соответствующей записи. Это позволяет более точно связать дневниковые записи с другими историческими источниками, существенно дополнить картину событий, полученную из других носителей исторической информации. Объективность фиксации информации в дневниках, по сравнению с мемуарами, отличается более высоким уровнем, поскольку они обычно не предназначены для обнародования и не подвергаются переработки автором, а сами фиксируемы события еще не рассматриваются в контексте взаимосвязей событийного ряда в целом, вне оценочных суждений самого автора и общества о них, появляющихся со временем, и т.п.

Ретроспективность дневников отличается фиксацией событий с более точной их хронологической фиксацией, создает своеобразную систему взаимосвязанных координат времени и прошедших событий. Нередко дневниковые записи связаны и с описанием места происходивших событий. Но при этом автор дневника представляет текущую информацию о событиях - по мере того, как они разворачиваются, описывает их внешнюю сторону. Данное свойство дневников позволяет их связать и обеспечить согласованное исследование отражение событий его автором в других источниках личного происхождениях (письмах, мемуарах).

Субъективность дневников проявляется в личности их создателя и определяется ими. На них влияют жизненные представления автора, возраст, образование, профессиональные и общественные интересы, круг общения, место проживания, а также их изменения. При этом по отношению к мемуарам дневники характеризуются относительно низким уровнем субъективности, поскольку присутствуют, как правило, незначительный временной разрыв между дневниковыми записями и описываемым событием. Субъективность дневников также характеризуется тем, что текущие события проходят через оценку автором, фиксируются по его усмотрению и отражают его взгляд на значимость события.

Частная переписка как исторический источник личного происхождения в качестве носителя информации опирается на частное письмо как личное обращение автора к определенному человеку - одному (или нескольким) адресатам и предназначено, как правило, для приватного ознакомления именно данным лицом. Такие письма пишутся не для публичного обнародования (печати, доведения до общего све- 


\section{Политика и общество 3 (111) • 2014}

дения) и не предполагают (полностью или частично) ознакомления с ним «третьих лиц». Для обозначения материалов частной переписки в целом употребляется понятие «эпистолярные источники». При этом материалы официальной переписки по утвердившейся в источниковедческой литературе традиции относят к материалам делопроизводства.

Документальность частной переписки близка к дневниковым записям, поскольку письмо наряду с оперативной фиксацией информации позволяет его синхронизировать как с происходящими событиями, так и с другими историческими источниками. При этом непредназначенность писем для публичного обнародования повышает уровень их объективности в передаче исторической информации, проходящей через их оценку автором. Последнее, в условиях диалогового общения адресатов, особенно интересно для выявления суждений автора письма и его адресата о происходящих событиях. Устойчивыми элементами эпистолярного памятника является указание адресата, места написания и даты, обращение к адресату, подпись автора письма. Но в содержании личного письма автор совсем свободен - он может писать о служебных, семейных, личных делах

Ретроспективность частной переписки, как и дневниковых записей, отличается хронологической фиксацией событий (закрепляет дату и место написания) и описывает их Это свойство эпистолярных источников позволяет их связать и обеспечить согласование с другими источниками (дневники, мемуары).

Субъективность дневников проявляется через личность их создателя и выбранного им адресата. Последнее подчеркивает характер социальных связей автора письма, направленность содержания и характера передачи информации, рассуждений, диалога с адресатом. Уровень субъективности писем может варьироваться в широких пределах - от краткой фиксации событий, до широкого спектра личных оценок и суждений. При этом в письмах, особенно отправленных неофициальным путем, могут быть интересные подробности и суждения о событиях, которые могли быть опущены или сглажены в связи с опасением перлюстрации корреспонденции. Необходимо и учитывать. То, что в связи с контролем над перепиской лица, находящиеся в переписке, могут использовать известные только им выражения и сокращения, «эзопов язык» и т.п.

Mемуары как разновидность источников личного происхождения представляют воспоминания участника или очевидца исторических событий. Им прису- щи все указанные общие свойства источников личного происхождения, но они имеют и определенную специфику, могут быль классифицированы по различным основаниям ${ }^{25}$. Документальность мемуаров основывается на письменных свидетельствах очевидцев описываемых событий и с точки зрения отражения действительности помогают восстановить факты, которые не отразились в других источниках, и нередко иметь решающее значение для реконструкции событий. Мемуаристика дополняет сведения о прошлом, полученные из других источников, уточняют их, восполняют лакуны в ранее полученной исторической информации. На документальность мемуаров, обращал внимание П.А. Зайончковский - «Ценность мемуаров заключается в изложении фактической стороны описываемых событий, а не в оценке их, которая, естественно, почти всегда субъективна» ${ }^{26}$. Но при этом необходимо учитывать то, что мемуары выступают как документально-литературные произведения и им принадлежит «особое качество документальной литературы, - отмечает Л. Гинзбург, в той установке на подлинность, ощущение которой не покидает читателя, но которая далеко не всегда равна фактической точности» ${ }^{27}$.

Ретроспективность мемуаров как исторических источников их необходимая и неотъемлемая черта. Но при этом она, как указывает И.Л. Сиротина, «не всегда бывает положительной». Поэтому «при обращении к мемуарному источнику следует учитывать, что от величины разрыва между событиями, отраженными в воспоминаниях, и временем их написания в определенной степени зависит и правдивость фактических данных, и точка зрения автора. Чем больше этот разрыв, тем больше нарастает вероятность ошибок памяти. Отдаленность времени написания воспоминаний от описываемых событий множит в воспоминаниях разного рода ошибки, причем помимо забвения фактов, наблюдаются искажения, которые в экспериментальной психологии носят название «мечтательной лжи», когда «в памяти затуманивается далекое прошлое, и желаемое выдается за действительность»»» ${ }^{28}$

\footnotetext{
${ }^{25}$ Шеретов С.Г. Проблемы классификации мемуарных источников в советской историографии источниковедения // Вестник Университета Кайнар. 2002. № 2.

26 Зайончковский П.А. Введение // История дореволюционной России в дневниках и воспоминаниях. М., 1976. С. 4.

${ }^{27}$ Гинсбург Л.Я. Указ. соч. С. 7.

${ }^{28}$ Сиротина И.Л. Культурологическое источниковедение... C. 228.
} 
Субъективность мемуаров выступает как неотъемлемое их качество, которое со всей очевидностью и полнотой проявляется в данном виде источников личного происхождения. И, казалось бы, серьезно препятствует получению из них достоверной информации. Так, Е.В. Тарле акцентировал внимание на том, что главная черта мемуарной литературы именно в ее чрезвычайно субъективном характере, поскольку «у автора есть совершенно сознательное намерение показать людей и их поступки лишь в известном освещении: выявит одно, скрыть другое, извратить третье». Он отдавал приоритет архивным документам ${ }^{29}$. Тем не менее, даже такое осторожное отношение к мемуарам не мешало историку активно их использовать в исследовательской деятельности при условии критического отношения к данному виду исторических источников.

Отечественное историческое источниковедение сформулировало правила оценки субъективного начала в мемуарах. Достаточно четко их представил С.А. Никитин - «Первой задачей историка, использующего мемуары, является выяснение, кто был их автором; ... какие побудительные причины толкали автора написать мемуары, какую задачу преследовал он, совершая эту работу, какова его точка зрения? Проделывая эту часть критической работы, следует всегда обращать особое внимание на наличие или отсутствие перемен в мировоззрении автора мемуаров и на соотношение точки зрения его в момент совершения событий с теми взглядами, какие оп имел в момент написания мемуаров». Он также определяет ряд вопросов «об источниках и степени осведомленности автора» мемуаров, которые предупредят ошибки исследователя: «Необходимо выяснить, был ли автор современником и участником изображаемых событий. Если же он излагает их не на основе непосредственного личного знакомства с ними, то каково происхождение и особенности сообщаемой им версии? Наличие сведений, заимствованных от других, вызывает вопрос о подготовленности и осведомленности этих лиц, заставляет проверять и собственные показания мемуариста и данные его источников. Необходимо при этом обратить внимание, является ли исследуемый документ плодом одного припоминания лично знакомых автору фактов или мемуарист создает ткань своих воспо-

29 Тарле Е.В. Значение архивных документов для истории // Вестник архивоведения. 1961. №3. С.102. минаний на основе какого-то документального материала - официальной переписки, частных писем, газетных сообщений и т.п.» ${ }^{30}$.

Мемуары позволяют глубже понять причины и взаимосвязь важнейших событий, а также то, как они воспринимались их участниками и свидетелями. В ряде случаев авторы воспоминаний вводят в научный оборот новые материалы или рассказывают о появлении того или иного документа, дают им собственную оценку. Не менее важными являются и оценки происходящих событий авторами источника, поскольку в них, как подчеркивает С.С. Минц, присутствует «... отражение ... степени осознания мемуаристами сущности явлений и процессов общественного развития, связи индивидуального и социального в общественной жизни» ${ }^{31}$.

Сказания иностранцев в российской исторической и историко-юридической науке выделялись в отдельную группу исторических источников. Отмечалось, что «под этим названием в русской исторической литературе, - как указывает Г. Лучинский, - известны записки, дневники, донесения, заметки и т. д. иностранцев, составленные на основании собственных наблюдений или по рассказам других лиц, побывавших в России» ${ }^{32}$.

Особое внимание к данному виду источников в середине XIX в. привлек В.О. Ключевский, работа которого «Сказания иностранцев о Московском государстве» обобщила имеющиеся в распоряжении историка различного рода носители информации о России, исходящие от пребывавших в русских землях иностранцев. Детальное освещение содержания «сказаний иностранцев», сделанное В.О. Ключевским, акцентирует внимание на различных характеристиках жизнедеятельности, но особое значение имеют его характеристики относительно государственно-правовых аспектов. Автор специально выделяет их в разделах «Государь и его двор», «Управление и судопроизводство», «Войско», «Прием иностранных послов в Москве». Он указывал на необходимость научной критики данного вида источников личного проис-

\footnotetext{
${ }^{30}$ Никитин С.А. Курс источниковедения истории СССР. M. 1940. T. 2. C. 100

${ }^{31}$ Мини С.С. Об особенностях эволюции источников мемуарного характера (к постановке проблемы) // История СССР. 1979. № 6. С. 64.

32 Лучинский Г. Сказания иностранцев // Энциклопедический словарь. Т. 30. СПб, 1900. С. 159-161.
} 


\section{Политика и общество 3 (111) • 2014}

хождения - «Понятно, как разборчиво и осторожно надобно пользоваться известиями иностранцев о Московском государстве: за немногими исключениями, они писали наугад, по слухам, делали общие выводы по исключительным, случайным явлениям, а публика, которая читала их сочинения, не могла ни возражать им, ни поверять их показаний» ${ }^{33}$. В $1860-$ 1870-е гг. в российскими востоковедами изучались и были публикованыя «сказания мусульманских писателей о славянах и руссах» (А.Я. Гаркави, Д.А. Хвольсон и др.), которые расширили источниковую базу исследования истории России ${ }^{34}$.

Данный вид носителей информации включался и в источники «истории права». Так, например, Д.Я. Самоквасов в качестве носителя историко-юридической информации «сказания иноземных писателей» и акцентировал взимание на том, что «иноземные литературные памятники ... составляют сведения об условиях политико-юридического быта наших предков языческой эпохи, сохранившиеся в сочинениях греческих, латинских, немецких и арабских писателей до X столетия включительно» и дал их достаточно подробный обзор как источников изучения формирования древнерусского права ${ }^{35}$. Он также их активно вводит в учебный процесс при подготовке юристов $^{36}$. Н.П. Загоскин также выделял указанный вид исторических источников в отдельную группу и указывал - «Под сказаниями или записками иностранцев разумеются сведения, доставляемые нам чужеземными писателями, или лично посещавшими наше отечество, или писавшие о нем по наслышке, на основании данных, добытых из вторых рук. Сведения подобного рода находим мы изложенными или в произведениях, специально посвященных описа-

\footnotetext{
${ }^{33}$ Ключевский В.О. Сказания иностранцев о Московском государстве М., 1866. С. 20.

${ }^{34}$ См.: Сказания мусульманских писателей о славянах и русских (с половины VII века до конца Х века по Р.Х.). Собрал, перевел и объяснил А.Я. Гаркави. СПб., 1870; Известия о хозарах, буртасах, болгарах, мадьярах, славянах и руссах Абу-Али Ахмеда бен Омар Ибн-Даста, неизвестного доселе арабского писателя X века, по рукописи Британского музея. В первый раз издал, перевел и объяснил Д.А. Хвольсон. СПб., 1869.

${ }^{35}$ Самоквасов Д.Я. Исследования по истории русского права. М., 1896. Вып. 2. С. 13-33.

${ }^{36}$ Самоквасов Д.Я. Средства познания древнейшего русского права. Пособие для практических занятий студентов. М., 1899.
}

нию нашего отечества или тех или других событий исторической жизни его, или же в произведениях, преследующих иные цели, в которых только мимоходом, случайно можем мы найти более или менее обильные сведения, могущие нам дать материал для русской истории» ${ }^{37}$. Российскими историками права также были разработаны основы методики работы со «сказаниями иностранцев», а также общие критерии их научной критики.

Итак, показанные отдельные разновидности источников личного происхождения позволяют сориентироваться в них с учетом специфики отражаемой исторической информации. Учет этих особенностей позволяет исследователю их учесть при исследовании различного рода процессов жизнедеятельности общества в прошлом, расширить палитру представлений о нем.

5. Источники личного происхождения в изучении государственно-правового развития России. Ценность использования источников личного происхождения в исследовательской деятельности состоит в понимании исследователем именно пересечения ретроспективно-документального и субъективно-личностного восприятия, отраженного в многогранных носителях информации данного вида. Уже в XIX столетии в исторической и историко-юридической науке данный вид исторической информации рассматривался, как отмечал относительно мемуаров историк Н.Д. Чечулин, средством изучения прошлого, которое позволяет исследователю «стать посреди событий известной эпохи» ${ }^{38}$. Историк права Н.П. Загоскин рассматривал мемуары в качестве одного из значимых носителей информации для понимания политико-правовых процессов - «Значение ... записок ... очевидно: авторы их жили в описываемую эпоху, имели более или менее близкое отношение или к самим событиям, в них воспроизводимым, или же к лицам, игравшим активную роль в этих событиях; вследствие этого в записках находим мы отражение того впечатления, которое произвели на современников те или иные события, находим указание на непосредственное отношение их к жизни общества, знакомимся, наконец, с такими подробностями и, нередко, закулисными чертами описываемых событий, сведе-

37 Загоскин Н. П. История права русского народа. Казань, 1899. Т. 1. С. 228-229. См. также с. 230-239.

38 Чечулин Н.Д. Мемуары, их значение и место в ряду исторических источников. СПб., 1891. С. 4 
ния из которых не могут быть почерпнуты ни из каких других источников официального характера» ${ }^{39}$.

Следует учитывать, что источники личного происхождения могут выступать уникальным средством изучения прошлого. По этому поводу Н.П. Матханова подчеркивает - «Мемуары часто содержат уникальные сведения, факты, отсутствующие в других источниках: о закулисной стороне процессов выработки политических решений, подлинной роли отдельных лиц, истинном авторстве сочинений и документов и т.д. Они особенно ценны при изучении истории общественного сознания, повседневности, при создании биографий. Благодаря мемуарам могут быть воссозданы исторический фон, на котором развивались события, атмосфера и колорит эпохи. Иногда в их текстах сохраняются документы, письма. В ряде случаев мемуары - единственный или главный источник наших знаний о тех или иных событиях или их аспектах. Немалую ценность имеют сведения об отдельных людях, их взглядах, действиях, привычках. Различия в индивидуальных впечатлениях дают возможность расширить и обогатить представления об исторических событиях и известных деятелях. Мемуары являются источником по истории не только той эпохи, которая в них описывается, но и той, в которую они создаются» ${ }^{40}$.

На историко-политический контекст информации в мемуарах обращает внимание П.А. Зайончковский - «Без обращения к дневникам и воспоминаниям буквально невозможно изучение целого ряда сторон исторического процесса и, в первую очередь, вопросов внутренней и внешней политики. Материалы официального делопроизводства ... освещают лишь одну сторону вопроса - официальную. Дневники, а также воспоминания дают представление о другой - закулисной стороне изучаемого явления, позволяют уточнить приводимые в официальных материалах сведения» ${ }^{41}$. Эти замечания весьма актуальны и для историков права. Лишь незначительная часть исследователей-юристов обращаются источникам личного происхождения.

Не обращаясь к конкретным источникам личного происхождения, подчеркнем, что тем имеющиеся справочные издания позволяют сориентироваться в массиве публикаций данного вида исторических источников.

39 Загоскин Н.П. История права русского народа. С. 221.

${ }^{40}$ Матханова Н.П. Мемуары // Историческая энциклопедия Сибири. Новосибирск, 2009. С. 346.

${ }^{41}$ Зайончковский П.А. Введение // История дореволюционной России в дневниках и воспоминаниях. М., 1976. Т. 1. С. 3.
Среди них особо значение издание «История дореволюционной России в дневниках и воспоминаниях. Аннотированный указатель книг и публикаций в журналах». Оно было опубликовано (в 5 т.) в 1976-1989 гг. под редакцией П.А. Зайончковского ${ }^{42}$. Это издание доступно в электронной библиотеке «Руниверс». В последние десятилетия были изданы источники, которые в советское время были недоступны по идеологическим соображениям или были существенно купированы цензурой.

Итак, общая характеристика основных разновидностей источников личного происхождения показывает их значение и особенности использования в исследовании прошлого. Выступая как субъективное отражение произошедших событий, данный вид исторических источников существенно расширяет палитру представлений о них. Они дополняют, а порой и представляют уникальную информацию, которая не содержится (или даже не может содержаться) в других исторических источниках.

$$
* * *
$$

Подводя итог, отметим, что источники личного происхождения выступают важным средством познания исторических и историко-юридических явлений. Данный вид исторических источников как носитель историко-юридической информации позволяет расширить характеристику развития государственных и правовых институтов и представить их не только в виде отражения организационно-регулятивных функций, но и показать черты различные стороны процесса институционализации государственно-правового развития. Исключительно большое значение источники данного вида имеют при изучении формирования идеологии государственно-правовых преобразований, биографии и политико-правовых взглядов мыслителей прошлого, системы взаимоотношений участников различных видов юридической деятельности, правосознания, правовой культуры и др. сторон жизнедеятельности общества в юридической сфере. Расширение привлечения источников личного происхождения в историко-юридических исследованиях позволит отойти от излишней опоры на источники официального происхождения, повысить познавательную значимость исследований юристов-историков.

\footnotetext{
${ }^{42}$ История дореволюционной России в дневниках и воспоминаниях. Аннотированный указатель книг и публикаций в журналах. М., 1976-1989. Т. 1-5.
} 


\section{Политика и общество 3 (111) • 2014}

\section{Библиография:}

1. Баженова Т.М., Кодан С.В. Личность, творчество и практическая деятельность юристов как отражение развития российской юриспруденции XI - начала ХХ вв. // Российское правосудие. 2010. № 9.

2. Биск И.Я. Мемуары // Советская историческая энциклопедия. М., 1966. Т. 9.

3. Гинсбург Л.Я. О психологической прозе. М., 1999. С. 7.

4. Данилевский И.Н., Кабанов В.В., Медушевская О.М., Румянцева М.Ф. Источниковедение: Теория. История. Метод. Источники российской истории. М., 1998.

5. Жожикашвили С.В. Дневник // Литературная энциклопедия терминов и понятий. М., 2001.

6. Загоскин Н.П. Курс истории русского права. Казань, 1906. Т. 1.

7. Загоскин Н.П. История права русского народа. Казань, 1899. Т. 1.

8. Зайончковский П.А. Введение // История дореволюционной России в дневниках и воспоминаниях. М., 1976. Т. 1.

9. Известия о хозарах, буртасах, болгарах, мадьяpax, славянах и руссах Абу-Али Ахмеда бен Омар Ибн-Даста, неизвестного доселе арабского писателя X века, по рукописи Британского музея. В первый раз издал, перевел и объяснил Д.А. Хвольсон. СПб., 1869.

10. История дореволюционной России в дневниках и воспоминаниях. Аннотированный указатель книг и публикаций в журналах. М., 1976-1989. Т. 1-5.

11. Кабанов В.В. Источниковедение истории советского общества. Курс лекций. М., 1997.

12. Ключевский В.О. Сказания иностранцев о Московском государстве М., 1866.

13. Ковальченко И.Д. Методы исторического исследования. М., 1987.

14. Лучинский Г. Сказания иностранцев // Энциклопедический словарь. СПб, 1900. Т. 30.

15. Матханова Н.П. Мемуары // Историческая энциклопедия Сибири. Новосибирск, 2009.

16. Мемуары // Энциклопедический словарь. Т. 19. СПб, 1896.

17. Миллер Дж.А. Магическое число семь плюс или минус два. О некоторых пределах нашей способности перерабатывать информацию // Хрестоматия по общей психологии. Психология памяти. M., 1980.
18. Минц С.С. Об особенностях эволюции источников мемуарного характера (к постановке проблемы) // История СССР. 1979. № 6.

19. Никитин С.А. Курс источниковедения истории CССР. М. 1940. Т. 2.

20. Петровская И.Ф. Биографика. Введение в науку и обозрение источников биографических сведений о деятелях России 1801-1917 годов. СПб., 2003.

21. Пушкарев Л.Н. Классификация русских письменных источников по отечественной истории. М., 1975.

22. Репина Л.П. Концепции социальной и культурной памяти в современной историографии. М., 2005.

23. Самоквасов Д.Я. Исследования по истории русского права. М., 1896. Вып. 2.

24. Самоквасов Д.Я. Средства познания древнейшего русского права. М., 1899.

25. Сиротина И.Л. Культурологическое источниковедение: проблема мемуаристики // Методология гуманитарного знания в перспективе XXI в. Мат. межд. научн. конф. СПб., 2001. Cep. «Symposium». Вып. № 12.

26. Сказания мусульманских писателей о славянах и русских (с половины VII века до конца X века по Р.Х.). Собрал, перевел и объяснил А.Я. Гаркави. СПб., 1870.

27. Тарле Е.В. Значение архивных документов для истории // Вестник архивоведения. 1961. № 3.

28. Тартаковский А.Г. 1812 год и русская мемуаристика. М., 1980.

29. Тартаковский А. Г. Русская мемуаристика XVIII первой половины ХІХ вв. М., 1991.

30. Чечулин Н.Д. Мемуары, их значение и место в ряду исторических источников. СПб., 1891.

31. Шеретов С.Г. Проблемы классификации мемуарных источников в советской историографии источниковедения // Вестник Университета Кайнар. 2002. № 2 .

32. Якушева Г.В. Мемуары // Литературная энциклопедия терминов и понятий. М., 2001.

\section{References (transliteration):}

1. Bazhenova T.M., Kodan S.V. Lichnost', tvorchestvo i prakticheskaya deyatel'nost' yuristov kak otrazhenie razvitiya rossiiskoi yurisprudentsii KhI - nachala KhKh vv. // Rossiiskoe pravosudie. 2010 . № 9. 
2. Bisk I.Ya. Memuary // Sovetskaya istoricheskaya entsiklopediya. M., 1966. T. 9.

3. Ginsburg L.Ya. O psikhologicheskoi proze. M., 1999. S. 7.

4. Danilevskii I.N., Kabanov V.V., Medushevskaya O.M., Rumyantseva M.F. Istochnikovedenie: Teoriya. Istoriya. Metod. Istochniki rossiiskoi istorii. M., 1998.

5. Zhozhikashvili S.V. Dnevnik // Literaturnaya entsiklopediya terminov i ponyatii. M., 2001.

6. Zagoskin N.P. Kurs istorii russkogo prava. Kazan', 1906. T. 1.

7. Zagoskin N.P. Istoriya prava russkogo naroda. Kazan', 1899. T. 1.

8. Zaionchkovskii P.A. Vvedenie // Istoriya dorevolyutsionnoi Rossii v dnevnikakh i vospominaniyakh. M., 1976. T. 1.

9. Kabanov V.V. Istochnikovedenie istorii sovetskogo obshchestva. Kurs lektsii. M., 1997.

10. Klyuchevskii V.O. Skazaniya inostrantsev o Moskovskom gosudarstve M., 1866.

11. Koval'chenko I.D. Metody istoricheskogo issledovaniya. M., 1987.

12. Luchinskii G. Skazaniya inostrantsev // Entsiklopedicheskii slovar'. SPb, 1900. T. 30.

13. Matkhanova N.P. Memuary // Istoricheskaya entsiklopediya Sibiri. Novosibirsk, 2009.

14. Memuary // Entsiklopedicheskii slovar'. T. 19. SPb, 1896.

15. Miller Dzh.A. Magicheskoe chislo sem' plyus ili minus dva. O nekotorykh predelakh nashei sposobnosti pererabatyvat' informatsiyu // Khrestomatiya po obshchei psikhologii. Psikhologiya pamyati. M., 1980.
16. Mints S.S. Ob osobennostyakh evolyutsii istochnikov memuarnogo kharaktera (k postanovke problemy) // Istoriya SSSR. 1979. № 6.

17. Nikitin S.A. Kurs istochnikovedeniya istorii SSSR. M. 1940. T. 2.

18. Petrovskaya I.F. Biografika. Vvedenie $\mathrm{v}$ nauku i obozrenie istochnikov biograficheskikh svedenii o deyatelyakh Rossii 1801-1917 godov. SPb., 2003.

19. Pushkarev L.N. Klassifikatsiya russkikh pis'mennykh istochnikov po otechestvennoi istorii. M., 1975.

20. Repina L.P. Kontseptsii sotsial'noi i kul'turnoi pamyati v sovremennoi istoriografii. M., 2005.

21. Samokvasov D.Ya. Issledovaniya po istorii russkogo prava. M., 1896. Vyp. 2.

22. Samokvasov D.Ya. Sredstva poznaniya drevneishego russkogo prava. M., 1899.

23. Sirotina I.L. Kul'turologicheskoe istochnikovedenie: problema memuaristiki // Metodologiya gumanitarnogo znaniya $\mathrm{v}$ perspektive XXI v. Mat. mezhd. nauchn. konf. SPb., 2001. Ser. «Symposium». Vyp. № 12 .

24. Tarle E.V. Znachenie arkhivnykh dokumentov dlya istorii // Vestnik arkhivovedeniya. 1961. № 3.

25. Tartakovskii A.G. 1812 god i russkaya memuaristika. M., 1980.

26. Tartakovskii A. G. Russkaya memuaristika XVIII pervoi poloviny XIX vv. M., 1991.

27. Chechulin N.D. Memuary, ikh znachenie i mesto v ryadu istoricheskikh istochnikov. SPb., 1891.

28. Sheretov S.G. Problemy klassifikatsii memuarnykh istochnikov $\mathrm{v}$ sovetskoi istoriografii istochnikovedeniya // Vestnik Universiteta Kainar. 2002. № 2.

29. Yakusheva G.V. Memuary // Literaturnaya entsiklopediya terminov i ponyatii. M., 2001. 